\title{
ILLEGAL URBAN ENTREPRENEURSHIP? THE CASE OF STREET VENDORS IN LAGOS, NIGERIA
}

\author{
Taibat Lawanson
}

Senior lecturer at Department of Urban and Regional Planning, University of Lagos, Nigeria

e-mail: tlawanson@unilag.edu.ng

\begin{abstract}
This paper considers the vulnerabilities experienced in making a living as a street trader in Lagos, Nigeria. Using the Tejuosho - Yaba - Ojuelegba - Barracks quadrant as a case study, the paper investigates the socio-economic profile of street traders, their basic survival strategies and goes further to examine the interface between street vendors and related urban stakeholders. Relying on both qualitative (informed participant interviews) and quantitative (survey by purposive sampling) data analysis, the study revealed that most of the respondents were aged between 16 and 35 years old and operated subsistence enterprises which were begun due to unemployment and the high cost of the renting stalls at the nearby Yaba market. The major challenge experienced was the institutionalized harassment by KAI officials, which aided extortion by other local stakeholders. The paper concludes by highlighting the potentials of the informal economic sector.
\end{abstract}

Keywords: informal, illegal, Lagos, street trader

\begin{abstract}
ABSTRAK
Penelitian ini mempertimbangkan kerentanan yang dialami dalam mencari nafkah sebagai pedagang kaki lima di Lagos, Nigeria. Menggunakan kuadran Tejuosho Yaba - Ojuelegba - Barak sebagai studi kasus, penelitian ini menyelidiki profil sosial ekonomi pedagang kaki lima, strategi pertahanan dasar mereka dan lebih lanjut untuk menguji antara PKL dan stakeholder perkotaan terkait. Mengandalkan analisis data kualitatif (wawancara peserta diinformasikan) dan kuantitatif (survei secara purposive sampling), penelitian menunjukkan bahwa sebagian besar responden berusia antara 16 dan 35 tahun dan menjalankan usaha subsisten yang dimulai karena pengangguran dan tingginya biaya kios-kios sewa di dekat pasar Yaba. Tantangan utama yang dialami adalah pelecehan yang dilembagakan oleh pejabat KAI, yang dibantu pemerasan oleh para stakeholder lokal lainnya. Penelitian ini diakhiri dengan menyoroti potensi sektor ekonomi informal.
\end{abstract}

Kata kunci: informal, illegal, Lagos, pedagang kaki lima 


\section{INTRODUCTION}

Street trading is a ubiquitous phenomenon in cities around the world (Dimas, 2008). It is possibly the most visible and significant informal economic activity (Jimu, 2005; Willemse, 2011) and can be described as an income-generating activity where individuals sell their wares along streets, sidewalks and major traffic nodes to passing pedestrians and motorists (Adiko \& Anoh, 2004; Kamunyori, 2007, Adhikari, 2011). The activity falls among the micro, small and medium enterprises (MSME) that form the main thrust for economic development in developing countries (Charmes, 1998; Mitullah, 2004). Estimating the number of street vendors is not easy due to the nature of their operations, especially since their numbers vary depending on time of the day or season of the year (ILO 2002), however, studies show that in many African cities, street trading is estimated to account for the largest share of informal jobs (between 15-25\%) and between $10-20 \%$ of total employment (Charmes, 1998; Herera et al, 2011).

Across African cities, street trading has been identified as a thriving activity that is an immediate response to landlessness, retrenchment and poverty and a significant contributor to urban and national economic development, especially because unemployment and poverty problems are more acute (Bromley, 1998; Cross, 2000; Budlender et al , 2001; Tsitsi, 2003, Lund et al, 2000; Mitullah, 2003). However, traders are usually in an adversarial relationship with city governments who view them as an urban management challenge and general environmental nuisance (ILO, 2006). The case of Lagos, Nigeria's premier city is a typical example as the Lagos State Ministry of Environment (2011) categorizes street trading alongside open defecation, urination in open places and dumping of refuse in drains as examples of environmental abuse and uncivilized dispositions, punishable with goods forfeiture, fines of up to $\$ 33(\mathrm{~N} 5,000)$ and imprisonment for up to six months for first time offenders.

While Lagos has an economy of about \$50billion and accounts for about $20 \%$ of Nigeria's GDP, more than half of her residents live below the poverty line and almost $75 \%$ of the working population are involved in the informal economy (NBS, 2011, UN-Habitat, 2012). With a vision to make Lagos Africa's model megacity and global economic and financial hub, the Lagos State government considers informality as being incompatible with the Mega-city Project (Kamunyori, 2007; Basinkski, 2009). As such, the poor, who are constrained to survive in informal systems, are constantly faced with institutional hostility, either through the declaration of their livelihoods (informal economic activities) as illegal or the frequent threat of eviction from their homes (informal settlements). Particularly vulnerable are the street traders whose activities are prohibited severally by the Lagos State Environmental Sanitation Law of 2000, the Lagos State Street Trading and Illegal Markets (Prohibition) Law of 2003, Lagos State Waste Management Authority Law of 2007 and the Lagos State Road Traffic Law of 2013. Furthermore, a special court as well as an enforcement unit (Kick Against Indiscipline (KAI), were set up primarily to control and possibly eradicate street trading across the Lagos Metropolis. 
In spite of these challenges and many more such as the pressures and demands from more powerful urban stakeholders such as local bosses, tax controllers and policy-makers (Fernandez-Kelly \& Shefner, 2006; Skinner, 2008; Pattiradjawane, 2013), street vending is ubiquitous on the streets of Lagos. Literature espouses many reasons for this, including poverty, widespread unemployment, inadequate market stalls as well as the prohibitive costs of rent in existing markets (Ayeni, 1980; Olaniyan, 1988, Adeagbo, 1997). Atoyebi (1984) opined that street trading thrives because of traffic congestion occasioned by poor road conditions, while poor market designs and unviable market locations can also be responsible for situations where people reject government provided marketplaces and embrace street trading.

This paper therefore attempts to understand why and how this cadre of the informal economy thrives in Lagos. The study investigates socio-economic characteristics of street traders, as well as their employment conditions and how they negotiate livelihoods in the face of their 'illegal' status, leaning on an urban citizenship theoretical construct. Similar studies which outline the challenges street traders face and their strategies for overcoming these challenges have been carried out in cities of Latin America (de Soto, 1989; Bromley, 1990; Ferragut, 2009), Asia (Bhowmik, 2000; Suharto, 2003, Williams \& Gurtoo, 2012), and Africa (Mitullah, 2003, 2010; Asiedu \& Agyei-Mensah,2008; Nnkya, 2006; , 2011, Adaarwen \& Jørgensen, 2012). Studies in Nigerian cities are many (Pearse et al, 1998; Ekpeyong \& Sibiri, 2011; Abe, 2012), but there is no recent evidence of such in Lagos, hence the necessity at this time. The study is also important, given Moser (1978) submission that the political dimensions of development planning can no longer be ignored and more recently, and Simone's (2004) position that any serious attempt to reinvent African urban centres must acknowledge and incorporate existing local knowledge that sustains and recreates informal urban economic social systems.

\section{The Study Area}

The study area is in the vicinity of Yaba Market, a major commercial centre that serves the entire metropolis. This area was chosen because there was a significant increase in street traders in the aftermath of the Tejuosho Market fire of December 2007.

Tejuosho market was made up of tiny stores on three floors with different sections for everything from clothing and groceries to fresh produce and vehicle parts. Though congested, it served all cadres of society, both traders and customers and all income levels were represented, from local fruit vegetable sellers at the kee-klamp section to the large-scale fabric merchants who rented multiple shops. After the fire incident which razed a section of the market in 2007, the Lagos State government took advantage to demolish the entire market, and remodel it to an ultra modern shopping mall, through a public-private partnership concessionaire agreement. The new market whose completion date has been severally shifted is meant to have 1648 shops in a 5-storey complex. According to the special consultant for the project, Wayne Bushell, 'The new market would enhance the landscape of the city'. Prices of shopping space are clearly out of the reach of the former occupants, with the smallest shop $(3 \times 3 \mathrm{~m})$ going for a price of $\$ 13,800(\mathrm{~N} 6.9 \mathrm{~m})$ as at October 2013. 
Thus average floor space in the market would go for about $\$ 7,000(\mathrm{~N} 1 \mathrm{~m})$, compared to $\$ 400(\mathrm{~N} 60,000)$ in 2007 . Former occupants are given first priority, expected to make $30 \%$ down payment and complete payment within five years at an interest rate of $18 \%$ per annum. Many of these displaced traders, decided to remain in the market area for locational advantage, and being unable to afford the exorbitant rents, resorted to displaying their wares on the streets and along the rail track.

\section{Criminalizing the Livelihoods of the Urban Poor: A Literature Overview}

Though the right to the city debate advances the rights of all urban dwellers to participate in shaping the city (Harvey, 2003; Lamarca, 2012), urban space is currently being used as an exclusionary tool against the poor (MacPherson \& Ziervogel (2012); Pietro, Sclar, \& Carolini, 2006). From the pioneering work of Lefebvre (1968), through studies over time (Harvey, 1973, 2003; Mitchell, 2003, Purcell, 2002, Brown \& Kristiansen, 2009), the right to the city enfranchises all citizens to participate in the use and production of urban space (Purcell 2002). However, urban management in developing countries has focused mostly on achieving 'world class city' status, attractive to international financial investment. This has resulted in a state where the poor are seen as undesirable in the modern city being created and come in contact with the economic development policies through the action of the state to impose order and exert control, using a tool kit of regulation, licensing, landuse planning and the interpretation of law afforded to various authorities (Robinson, 2002; Potts, 2007; Watson, 2009; Charman, Petersen \& Piper, 2012).

Partiality towards modern infrastructure has resulted in a situation where projects such as construction of new shopping malls or new roads are prevalent (Brown, 2006). According to Cross (2000), third world governments created the impression that 'the presence of large street markets, for example, was the clearest sign of the 'disorder' and 'willfulness' of the informal economy that needed to be stamped out. The situation in Lagos, where community markets are being replaced with shopping malls is a clear case.

Street trading is seen as an urban management issue, rather than an economic development concern. Street traders have been vilified as being responsible for multitude of urban challenges including waste management, traffic congestion and crime. They are seen as a clear manifestation of under-development, rather than a manifestation of urban resilience with clear potential (Sassen, 1997; Bromley \& Mackie, 2009, Cross \& Morales, 2007). As such, restrictive and punitive measures are constantly being designed to curtail their activities (Donovan, 2008; Skinner, 2010, Bob-Milliar \& Obeng-Odoom, 2011). Frequently at the receiving end of institutional repression, persecution and prosecution, these survivalist entrepreneurs are victims of social exclusion and the loss of meagre livelihoods (Bromley, 2000; Xaba et al, 2002; Berner et al, 2008). Literature reports that as much as $20 \%$ of the street traders earnings is taken as bribes by the municipal authorities and their intermediaries (Bhowmik, 2005, 2007).

Fischer (2008) defines social exclusion as structural, institutional or agentive processes of repulsion or obstruction in which individuals and entire communities of people are systematically blocked from rights, opportunities and resources that are 
normally available to members of society and which are key to social integration. Saith (2001) identified street traders as a key urban cluster who are socially excluded. In summary, street vending involves negotiation for physical space, economic opportunity and urban citizenship, therefore this study will consider the activities of Lagos street traders from these contexts.

\section{THEORY / RESEARCH METHODS}

The study adopts a survey research design and the target population are street traders along major thoroughfares in the Tejuosho - Yaba - Ojuelegba Quadrant of Lagos. They were identified in four main categories: mobile hawkers along the street; stationery traders by the road side with wares in baskets, trays or wheelbarrows; semipermanent traders with wares on makeshift stalls or tables; permanent vendors operating from wooden kiosks and metal containers, confirming the literature which identifies categories of street traders (Charmes, 1998; Mitullah, 2006).

For the purpose of this research, both quantitative and qualitative data collection methods, gathered through key informant interviews and a field survey conducted through the administration of structured questionnaires by purposive sampling technique. To determine the sample frame, a fifteen hour (7am - 10pm) street trader count was conducted along the major streets (Ojuelegba, Tejuosho, Yaba Rail-line and Yaba bus-stop and Ojuelegba bus stop environs) in the area during the reconnaissance survey. This was a total of 641 of which $50 \%$ (320) was then set as the sample size. The survey involved structured interviews hence there was a $95 \%$ success rate as 306 questionnaires were retrieved in a good condition for further analysis. Data was collected on socio-economic characteristics of the traders, nature of their business operations, major challenges as how they negotiate their illegal status with well as relationships with the municipal authorities and market association. Variables include gender, age, education attainment, length and reasons for choice of business as well as form of business registration, membership of cooperative societies and major challenges encountered. Key informant interviews were conducted with a cross section of the sample population to get more personal views of experiences as street traders.

\section{RESULTS AND DISCUSSION}

\section{Socio Economic Profile of Respondents}

The variables considered in this section are age, gender, education, marital status, length of stay in the area, reason for choosing street vending as a vocation and average monthly income from street trading. 
Table 1. Socio-Economic Profile of Respondents

\begin{tabular}{|c|c|c|c|c|}
\hline & & $\begin{array}{l}\text { Male (\%) } \\
\mathrm{n}=171\end{array}$ & $\begin{array}{l}\text { Female }(\%) \\
n=135\end{array}$ & $\begin{array}{l}\text { Total }(\%) \\
n=306\end{array}$ \\
\hline \multirow[t]{5}{*}{ Age } & $16-25$ & 23.9 & 12.6 & 18.9 \\
\hline & $26-35$ & 34.5 & 42.2 & 37.9 \\
\hline & $35-45$ & 27.5 & 25.7 & 26.8 \\
\hline & $46-60$ & 11.1 & 17.3 & 14.7 \\
\hline & Above 60 & 2.9 & 2.2 & 1.7 \\
\hline \multirow{4}{*}{$\begin{array}{l}\text { Highest edu- } \\
\text { cation }\end{array}$} & None & 5.8 & 7.4 & 6.5 \\
\hline & Primary & 15.2 & 21.5 & 17.9 \\
\hline & Secondary & 60.7 & 51.8 & 57.2 \\
\hline & tertiary & 17.9 & 19.3 & 18.4 \\
\hline \multirow[t]{2}{*}{ Marital status } & Single & 69.1 & 34.8 & 43.8 \\
\hline & Married & 40.9 & 71.8 & 56.2 \\
\hline \multirow{4}{*}{$\begin{array}{l}\text { Length of stay } \\
\text { in area }\end{array}$} & Less than 1 year & 9.3 & 11.8 & 10.5 \\
\hline & $1-5$ years & 42.7 & 47.4 & 44.7 \\
\hline & 6-10years & 26.9 & 24.4 & 25.8 \\
\hline & Over 10years & 21.1 & 16.3 & 18.9 \\
\hline \multirow{3}{*}{$\begin{array}{l}\text { Why choice of } \\
\text { street trader }\end{array}$} & Unemployment & 47.4 & 54.1 & 50.3 \\
\hline & Lack of capital & 30.9 & 31.9 & 31.4 \\
\hline & Access to customers & 21.6 & 6.7 & 18.3 \\
\hline \multirow{3}{*}{$\begin{array}{l}\text { Secondary } \\
\text { occupation }\end{array}$} & None & 78.3 & 77.8 & 78.1 \\
\hline & Formal & 11.1 & 7.4 & 9.4 \\
\hline & Informal & 13.6 & 14.8 & 12.5 \\
\hline \multirow{5}{*}{$\begin{array}{l}\text { Average } \\
\text { monthly in- } \\
\text { come } \\
(\$ 1-N 150)\end{array}$} & Below $\$ 100$ & 36.9 & 46.6 & 43.2 \\
\hline & $\$ 100-180$ & 32.7 & 27.1 & 30.7 \\
\hline & $\$ 180-300$ & 21.6 & 20.8 & 21.9 \\
\hline & $\$ 300-500$ & 8.2 & 4.4 & 3.3 \\
\hline & Above $\$ 500$ & 0.6 & 1.1 & 0.9 \\
\hline
\end{tabular}

The study revealed a relatively balanced gender profiling as men made up $55.8 \%$ of respondents and women made up $44.2 \%$. However, while about $70 \%$ of male street vendors are single, $70 \%$ of women are married as shown in Table 1 . The respondents were quite young, with over 50\% aged less than 35years old, the national threshold for youth population, which tallies with national statistics that claim $49.3 \%$ of the urban unemployed and/or working poor are aged between 15 and 34 . (NBS, 2011).

The respondents are also quite literate, with about $57 \%$ having some form of secondary education and almost $20 \%$ having gone through tertiary education, thus refuting the general perception that street traders are school dropouts.

For majority of the respondents (78\%), street trading is their only source of income. Average monthly income of the respondents showed that women generally earned less than men, with about $47 \%$ of women and $40 \%$ of men earning less than the national minimum wage of $\$ 120(\mathrm{~N} 18,000)$. Reasons given for operating as 
street vendors include unemployment $(50.3 \%)$, lack of capital $(31.4 \%)$ and access to customers $(18.3 \%)$.

According to a female trader who sells cosmetics from a basket:

'I only had N10,000 when I was starting business two years ago, I can't afford to rent a shop out of that small amount of money, but I feed my children and send them to school from this trade'

Many of those who stayed in the market area because of customers had operated from within the market prior to the 2007 fire. When asked if they will consider returning to the market when it is opened, one trader who sells fabrics had this to say:

'These new shops are too expensive. Go to Lawanson Market, go to Olosha, go to Balogun, opposite Trade Fair Badagry and so on, because of the prices, the markets are empty. Markets in Lagos cannot exist without the masses and petty traders occupying them'

\section{General Business Overview}

The variables considered in this section are category of street trade, whether itinerant or stationary, commodity being traded, reason for choice of location, no of days spent vending weekly, type of business permit, business financing and major challenges experienced.

The respondents were mainly stationery, with $28.1 \%$ trading from kiosks usually branded. Hawkers moved around the market areas selling a myriad of items ranging from recharge cards to frozen fish, while the second hand clothing merchants displayed their wares on sacks along the rail line. Clothes, fashion accessories and cosmetics were the commodity most frequently traded. Majority of the traders $(38.2 \%)$ chose their location in order to enjoy more visibility and attract customers, while about a quarter chose their current location because they were less susceptible to harassment by law enforcement agents and community thugs there. As majority of them rely solely on income from street vending, close to $70 \%$ of them operate at least five days a week, with others choosing to do so once or twice a week. The wholesale fruit sellers belonged to this category as they travel to surrounding rural areas to source for fruit, which they distribute to those who retailed from wheelbarrows and baskets. Average time spent vending per day was about eight hours, with rest periods of between one to two hours.

The study revealed that most street traders had some form of registration as shown in Table 2. It was discovered that the most common was the association card (90\%). The study revealed that traders without association cards were disallowed from plying their trade in the area and that there were traders - usually association executive members - who enforced this, often violently. This card served as form of social security since the associations made periodic returns to the police and other power brokers. The market board receipt and local government permit was mandatory for those trading from fixed locations.

Major sources of business funding was by savings $(30.4 \%)$, rotating credit $(69.6 \%)$ and cooperative loans, obtained through the associations $(26.1 \%)$. It was 
also interesting to note that many of the traders also extended their business hours to late evening.

For example, a shoe trader along the railway line said:

'Even though we pay the market association, they don't protect us from arrest. So we don't usually come out in the morning or afternoon when they will be around but in the evening, we all troop out because by then, they (KAI brigade) would have closed from work.'

Table 2. Business Operations of Respondents

\begin{tabular}{|c|c|c|}
\hline & & $\begin{array}{c}\text { Total }(\%) \\
n=306\end{array}$ \\
\hline \multirow[t]{7}{*}{ Commodity traded } & Cooked food & 12.1 \\
\hline & Fruit and Vegetables & 14.4 \\
\hline & Tinned Foods & 19.3 \\
\hline & Fashion and cosmetics & 26.4 \\
\hline & Books/CD/ Magazines & 8.5 \\
\hline & Phone accessories/ recharge cards & 13.1 \\
\hline & Others & 6.2 \\
\hline \multirow[t]{4}{*}{ Location of space } & Hawkers & 18.6 \\
\hline & Basket, Tray, Wheelbarrow & 14.4 \\
\hline & Car, Stall, Table & 38.9 \\
\hline & Kiosk & 28.1 \\
\hline \multirow{4}{*}{$\begin{array}{l}\text { Reason for choice of } \\
\text { location }\end{array}$} & Less harassment & 25.9 \\
\hline & More customers & 38.2 \\
\hline & Can't afford shop & 23.8 \\
\hline & Close to home & 12.1 \\
\hline \multirow{4}{*}{$\begin{array}{l}\text { No of days spent vend- } \\
\text { ing per week }\end{array}$} & Everyday & 38.9 \\
\hline & Every week day & 30.7 \\
\hline & weekly & 18.6 \\
\hline & Once in a while & 11.8 \\
\hline \multirow[t]{4}{*}{ Business permit } & None & 17.6 \\
\hline & Association card & 90.5 \\
\hline & Market Board Receipt & 84.3 \\
\hline & Local government permit & 71.5 \\
\hline \multirow[t]{3}{*}{ Source of financial aid } & Savings & 30.4 \\
\hline & Rotating credit & 69.6 \\
\hline & Cooperative Loan & 26.1 \\
\hline \multirow[t]{7}{*}{ Major challenges } & Weather & 12.1 \\
\hline & Finance & 27.1 \\
\hline & Harassment & 35.3 \\
\hline & Road Hazard & 4.9 \\
\hline & Health & 4.2 \\
\hline & Access to space & 11.1 \\
\hline & Lack of storage space & 5.2 \\
\hline
\end{tabular}


Another trader said:

'I stay at Nathan (an inner street) to sell books in the afternoon but come down to Yaba in the night to sell because there are multitude of people going home in the night.

\section{Negotiating Space for Street Vending}

This section considers how the street traders interface with the municipal authorities, KAI Officers and other stakeholders.

The respondents identified the following to be the major parties they interacted with in the course of their business activities: the market board; trade association; local touts (area boys); community leaders (Baale), municipal authorities; KAI officials and the Police. They paid tolls and levies to each of these bodies, either individually or through the various trade associations. These tolls were to secure their trade spot, licence to trade in specific commodity, protection of goods from confiscation, and in the case of the local touts, information and protection from violence. Table 3 shows the frequency of payment to each of the bodies.

According to one of the traders who sells electronic gadgets from the trunk of his car:

'Any available place, including walkways, street junctions, roads and footbridges being converted to market space is not for free, From Monday to Thursday, I pay N550 to the market board and on Fridays and Saturdays, it's N750 because it's weekend while on Sunday, we just pay N350. This is in addition to car-park fees.'

Table 3. Types of Tolls/ Levied Paid to Access Space for Trade

\begin{tabular}{|c|c|c|c|}
\hline & Nature of payment & $\begin{array}{l}\text { Frequency of } \\
\text { payment }\end{array}$ & $\begin{array}{l}\text { Minimum toll } \\
\text { collected }\end{array}$ \\
\hline Market board & Individual and Collective & Weekly & N500/ trader \\
\hline Trade Association & Individual & Weekly & N500/ trader \\
\hline Local Tout & Individual & Daily & N100/ trader \\
\hline Community Leader & Individual & Daily & N200/ trader \\
\hline Municipal authorities & Individual & Yearly & N2000/ stall \\
\hline KAI Officials & Collective & Weekly & Negotiated \\
\hline Police & Collective & Weekly & Negotiated \\
\hline
\end{tabular}

However, in spite of all these levies, the itinerant street traders especially are still vulnerable as they are frequently harassed, with the KAI officials' activities being the most burdensome.

The typical KAI Raid was described thus:

'They pulled down structures, break chairs and tables, seized some valuables, carry away some food, and other edibles, and throw the rest into the gutter, leaving confusion and destitution in their wake.' 
Within the preceeding six months, the street traders had had their goods confiscated $(32.2 \%)$ and subsequently retrieved after paying bribe $(18.8 \%)$, goods destroyed $(16.1 \%)$, been arrested for street trading and/or wandering $(9.6 \%)$ and evicted from their trade space $(21.6 \%)$.

A young man who hawks cold bottled water said:

'We cannot steal so we've been trying to earn a honest living, but it's been made difficult by the government; they don't like poor people.'

A woman who sells roasted plantains by the road side said:

'I do not have peace. Imagine an old woman like me running like a thief whenever I hear the sound of a siren or I see anybody in uniform. I cannot afford to pay for a shop that is why I am managing this small space. It's not as if it's for free, I am paying them for it yet nobody defends us when KAI people come.'

Another man who sells recharge cards said:

'Just last week I was arrested by KAI. They picked me up bundled me into their car. I had to part with some money before they released me. As you can see, I don't use a table anymore; rather, I walk up and down to sell my cards. I resorted to this method to be able to run away on time. The last time I was trying to dismantle my table when they caught up with me and I swore that next time they won't succeed so easily.

\section{Discussion and Policy Recommendations}

The study revealed that in spite of the contributions of street vending to urban survival in the study area, and the institutional mechanisms to eradicate the practice, street trading thrives on the streets of Lagos. The study revealed that for the Lagos State Government, urban development is equated with city beautification and infrastructure provision, synonymous with world class status; denying the fact the street trading is accepted in New York City, United States of America, Vancouver, Canada and Melbourne, Australia, some of the most liveable cities in the world (EIU, 2013).

The socio-demographic profile of the traders reveals a predominantly young population, who are solely dependent on street trading for survival. This is particularly evident among the women folk, $70 \%$ of whom are married. When contextualized, street trading is a direct response of the failure of the system to provide opportunities for these urban citizens to access the rights and privileges of the city. The street market provides vendors with an opportunity to make an independent income, promotes their well being and with sustained effort, climb out of poverty. It enables the working poor to enjoy the constitutional right to work when they otherwise would not be able to, as such, the paper aligns with the position of Sattherthwaithe and Hardoy (1993) which states that there must be something wrong with the law and attitude of government if the urban majority are forced to contravene laws daily in their search for daily survival holds true. 
For many of the traders who were displaced from the former market by the 2007 fire, the possibility of returning is quite slim as the new ultra modern shopping mall has been priced out of the reach of the average petty trader. It is interesting to note that modernization of this sector of the economy is largely being rejected as is reflected in the fact that in spite of the congestion on the streets surrounding the new market, most of the shops are yet to be procured.

The study revealed that the greatest challenge faced by the traders is the institutional harassment, especially from KAI brigade. However, this is in spite of the numerous tolls paid to both formal and informal urban actors. It therefore shows that this policy which criminalises the operations of street vendors only goes to further corruption, as many have been able to use this toga to extort the traders severally. While many embrace street vending as a low-cost alternative to criminal activity, the criminalization of self-help poverty mitigating behaviours has adverse effects on inclusive city building as it increases feelings of discrimination among vulnerable groups. The young demographic profile of the street traders is also important as they are the most susceptible to violent behaviour, as in the case of the Tunisian revolution which was triggered by a 26year old street trader protesting harassment by municipal authorities (Kareem, 2011). The repercussions are still being felt today.

By a simple policy shift, the urban managers in Lagos will be able to harness some of the latent potentials street vending holds for cities; and transiting form the use of law as a tool of control to use of law as a tool of empowerment (de Soto, 2000; Vargas, 2013). Conferring street trading a legal status will be a win-win situation for both parties. By recognizing the positive contributions street trading makes to the city economy, the authorities will be able to regulate the trade, govern a more inclusive city, while the operators' livelihoods will be secured as they will be protected from extortions and harassments.

Furthermore, they will be able to operate as urban citizens with a stake in the Lagos Megacity, while the environmental concerns of the authorities can be allayed by designating certain areas as 'street trading zones' where traders can operate subject to municipal regulations. By recognizing their membership of trade association and granting municipal trade licences to these associations and members, street traders can partner with the authorities to enforce the environmental sanitation, waste management and traffic management codes. This will go a long way towards bridging the gap between the government and the people on one hand, and towards the entrenchment of urban inclusiveness on the other.

\section{CONCLUSION}

This paper has attempted to highlight the conflicts that arise from the pursuit of politically motivated cosmetically managed human settlements, while stifling the entrepreneurial response of the poor to unemployment. These two should not be mutually exclusive. There should be a place for the poor in the vision of a viable megacity. Therefore, the study also attempted to develop strategies for developing inclusive cities which recognize the place of the informal economy in urban poverty alleviation and indeed the emerging African city form. 


\section{REFERENCES}

Abe, T. (2012), Bracing the odds in the face of double tragedy: The Dilemma of Street Trading in Ibadan Metropolis. Journal of Sustainable Development in Africa, 14(8), 1-15.

Adaawen, A.\& Jørgensen, H. (2012), Eking out a Living: The livelihood implications of urban space regulation on street hawking in Accra, Ghana, African Review of Economics and Finance, 3(2), 1-19.

Adeagbo, D. (1997), Physical and Socio-economic Impact of Street Trading: Case Study of Ibadan, NISER Monograph Series No. 10, 1997, Nigerian Institute of Social and Economic Research (NISER), Ibadan.

Adhikari, D. (2011), Income Generation in Informal Sector: A Case Study of the Street Vendors of Kathmandu Metropolitan City. Economic Journal of Development Issues, 13(1-2).

Adiko, A \& Anoh.K (2003), Activities and Organisation of Traders on the Markets and Streets of Ivory Coast: The Case of Cocody, Treichville, Yopougon, Communes and Some Streets in Abidjan, University of Cocody, Abidjan.

Asiedu, A. \& Agyei-Mensah, S. (2008), Traders on the run: Activities of street vendors in the Accra Metropolitan Area, Ghana, Norsk Geografisk TidsskriftNorwegian Journal of Geography, 62(3), 191-202.

Atoyebi, M. (1984), Alternative Strategies for the Resettlement of Street Traders in Ilorin, Unpublished M.U.R.P Thesis, University of Ibadan, Ibadan.

Ayeni, O. (1980), Street Trading in Ibadan, Focus on Lebanon-Amunigun-Feleye Agbeni and Gege Streets, Monograph of the Department of Town Planning and Estate Management, The Polytechnic, Ibadan.

Basinkski, S. (2009), All Fingers are not equal: A Report on street vendors in Lagos, Nigeria, CLEEN Foundation, Lagos.

Berner, E., Gomez, G. \& Knoringa.P (2008), The Logic of Survival Entrepreneurs and the Moral Economy of the Slum, Paper Presented at the UNU - WIDER Workshop 'Entrepreneurship and Economic Development', Helenski,

Bhowmik, S. (2000), Hawkers in the Urban Informal Sector: a Study of Street Vendors in Six Cities. Bangalore: National Alliance of Street Vendors of India, <www.nasvi.org > (Accessed on 13 January 2008)

Bhowmik, S. (2005), Street vendors in Asia: A review, Economic and Political Weekly, May 28-June 4, 2256-2264.

Bhowmik, S. (2007), Street Vending in Urban India: the Struggle for Recognition. In Cross, J. \& Morales, A. [eds], Street Entrepreneurs: People, Place and Politics in Local and Global Perspective, 89-123, Routledge, London.

Bob-Milliar, G. and Obeng-Odoom F. (2011), The Informal Economy is an Employer, a Nuisance and a Goldmine: Multiple Representations of and Responses to Informality in Accra, Ghana; Urban Anthropology, 40(3-4), 264285.

Bromley, R., \& Mackie, P. (2009), Displacement and the new spaces for informal trade in the Latin American city centre, Urban Studies, 46 (7), 1485-1506. 
Bromley, R. (1990), A New Path to Development? The Significance and Impact of Hernando de Soto's Ideas on Under-development, Production, and Reproduction, Economic Geography, 66, 328- 348.

Bromley, R. (1998), Informal commerce: Expansion and exclusion in the historic centre of the Latin American city, International Journal of Urban and Regional Research, 22(2), 245-263.

Bromley, R. (2000), Street Vending and Public Policy: A Global Review, International Journal of Sociology and Social Policy, 20(1-2), 1-28.

Brown, A. (2006), Contested Space: Street Trading, Public Space, and Livelihoods in Developing Cities, ITDG Publishing.

Brown, A. and Kristiansen, A. (2009), Urban Policies and the Right to the City: Rights, Responsibilities and Citizanship, UN-Habitat - Policy Paper Series on Management of Social Transformations.

Budlender, D. Buwembo, P. \& Shabala, N. (2001), 'Country Case Study: South Africa'; The Informal Economy: Statistical Data and Research Findings. ILO, Geneva.

Charman, A., Petersen, L. \& Piper, L. (2012), Informality disallowed? State restrictions on informal traders and micro-enterprises, Paper presented at the Towards Carnegie 3 Conference, September, Cape Town.

Charmes, J. (1998), Street Vendors in Africa: Data and Methods. United Nations Statistical Division, New York.

Charmes, J. (2000), Informal Scector, Poverty and Gender: A Review of Empirical Evidence; Background paper for WORLD Development Report 2001.

Cross, J. (1998), Informal Politics - Street Vendors and the Statei In Mexico City, Stanford, Stanford University Press, California.

Cross, J. (2000), Street Vendors, Modernity and Postmodernity: Conflict and Compromise in the Global Economy, International Journal of Sociology and Social Policy, 20(1-2), 30-52.

Cross, J., \& Morales, A. (2007), Introduction: Locating Street Markets in the Modern/Postmodern World.i In J. Cross \& A. Morales [eds], Street Entrepreneurs: People, Place and Politics in Local and Global Perspective, 1-13, Routledge, London.

de Soto, H. (1989), The Other Path: The Economic Answer to Terrorism, Harper and Row, London.

de Soto, H. (2000), The Mystery of Capitalism: Why Capitalism Triumphs in the West and fails everywhere else, Basic Books, New York.

Dimas, H. (2008), Street Vendors: Urban Problem and Economic Potential. Working Paper in Economics and Development Studies NO 200803, Padjadjaran University.

Donovan, M. (2008), Informal Cities and the Contestation of Public Space: The Case of Bogotá's Street Vendors, 1988-2003. Urban Studies, 45(1), 29-51.

The Economist Intelligence Unit (2013), Global Livability Report, The Economist. Available at <http://www.eiu.com/site_info.asp?info_name=The_Global_Liveability_Report> (Accessed on 2 January 2014). 
Ekpenyong, S. \& Sibiri, A. (2011), Street Trading and Child Labour in Yenegoa. Journal of Scientific Research in Education, 4(1), 36-46, <http://www.ijsre.com> (Accessed on 19 July 2012)

Fernández-Kelly, P \&Shefner, J (2006), Out of the Shadows: Political Action and the Informal Economy in Latin America, Pennsylvania State University Press, University Park, Pa.

Ferragut, S. (2009), From the Stall to the Store: The Formalization of Street Vendors in Quito, Equador. (MA Thesis), Institute of Social studies, The Hague.

Fischer.A (2008), Resolving the Theoretical Ambiguities of Social Exclusion with reference to Polarisation and Conflict, DESTIN Working Paper 08-90, London School of Economics, London.

Harvey, D. (1973), Social Justice and the City, Edward Arnold Publishers, London.

Harvey, D. (2003), Debates and Developments: The Right to the City, International Journal of Urban and Regional Research, 27(4), 939-941.

Herrera, J., Kuépié, M. Nordman, C., Oudin, X. \& Roubaud, F. (2011), Informal Sector and Informal Employment: Overview of Data for Eleven Cities in ten Developing Countries." In WIEGO Urban Policies Resource Document, <www.wiego.org> (Accessed on 20 June 2013).

International Labour Organization (2002), Decent Work and the Informal Economy, International Labor Office, Geneva.

International Labour Organization (2006), The Informal Economy, Labor Protection and Street Vending: Cambodia, India, Malaysia, Mongolia and Thailand, Bangkok, Thailand.

Jimu, I. (2005), Negotiated Economic Opportunity and Power: Perspectives and Perceptions of Street Vending in Urban Malawi, Africa Development, 20(4), $35-51$.

Kamunyori, S. (2007), A Growing Space for Dialogue: the Case of Street Vending in Nairobi's Central Business District. Unpublished MCP Thesis, Massachusetts Institute of Technology.

Kareem, F. (2011), Slap to a man's pride sets off tumult in Tunisia', New York Times, pp 2, January 21, 2011.

Lagos State Environmental Sanitation Law (2000)

Lagos State Ministry of Environment (2011), Transcript of Press Conference with Commissioner of Environment, Mr Tunji Bello, November 27, 2011.

Lagos State Road Traffic Administration Law, (2013)

Lagos State Street Trading and Illegal Markets (Prohibition) Law, (2003)

Lagos State Waste Management Authority Law, (2007)

Lamarca, M. (2012), The Right to the City: Reflections on Theory and Practice, <www.polis@wordpress> (Accessed on 18 June 2013).

Lefebvre, H. (1996), Right to the City, English translation of 1968 text in Kofman, E. \& Lebas, E. [eds and translators], Writings on Cities, Blackwell Publishing, Oxford.

Lund, F., Nicholson, J. \& Skinner, C. (2000), Street trading, School of Development Studies University of Natal, 2000. 
Macpherson, A \& Ziervogel, C. (2012), Settlements Under Siege: Securing Rights to the City, The Global Network of the Urban Poor Newsletter, <www.sdi.org> (Accessed on 5 September 2013).

Mitullah, W. (2004), A Review of Street Trade in Africa, USA: Kennedy School of Government, Harvard University - Review commissioned by WIEGO.

Mitullah, W. (2003), Street Vending in African Cities: Synthesis of Empirical Findings from Kenya, Cote d'Ivoire, Ghana, Zimbabwe, Uganda and South Africa. Washington DC, World Bank - A Contribution to World Development Report on Investment Climate and Informal Enterprises.

Mitullah, W. (2006), Street Vendors and Informal Trading: Struggling for the Right to Trade, <http://www.pambazuka.org/en/category.comment/34802> (Accessed on 11 January 2013).

Mitullah, W. (2010), Informal Workers in Kenya and Transnational Organising: Networking And leveraging Resources. Lindell. I [eds] Africa's Informal Workers, Collective Agency, Alliances and Transnational Organising in Urban Africa, Zed Books, London.

Moser, C. (1978), The informal Sector or Petty Commodity Production: Dualism or Dependence in Urban Development? World Development 6(9).

National Bureau of Statistics (2011), National Unemployment Report 2011, <www.nbs.org> (Accessed on 24 April 2013).

Ndlovu, P. (2011), Street Vendiing in Lusaka District. Unpublished MA Development Studies, Institute of Development Studies, Netherlands.

Nnkya, T. (2006), An Enabling Framework? Governance and Street Trading in Dar es Salaam, Tanzania, in Brown, A. [eds], Contested Space: Street Trading, Public Space, and Livelihoods in Developing Cities, Intermediate Technology Publica, Warwickshire.

Olaniyan, J. (1988) Environmental Performance of Urban Roadside Traders in Jos, Nigeria, Journal of Environmental Planning and Management, 31(1), 29-34.

Pearce, T., Kujore, O., \& Agboh-Bankole, V. (1988), Generating an income in the urban environment: The experience of street food vendors in Ile-Ife, Nigeria, Africa, 58(4), 385-400.

Pattiradjawane. H, Schnepf-Orth, M., \& Stoetzer, S. (2013): Negotiating Informal Urban Spaces. Female Cake Vendors at the Pasar Kue Subuh Senen Night Market in Jakarta, Indonesia. - Darmstadt: Technische Universität Darmstadt, 2013, <http://tuprints.ulb.tu-darmstadt.de/id/eprint3637> (Accessed on 11 February 2014).

Pietro, G., Garau, Sclar, E., and Carolini, G. (2006), Treating People and Communities as Assets, Global Urban Development Magazine. 2(1).

Potts, D. (2007), City Life in Zimbabwe at a time of Fear and Loathing: Urban Planning, urban Poverty and Operation Murambatsvina, in Myers, G. and Murray, M. [eds], Cities in Contemporary Africa, Palgrave Macmillan, New York.

Purcell, M. (2002), Excavating Lefebvre: the right to the city and its urban politics of the inhabitant, Geojournal, 58, 99-108.

Robinson, J. (2002), Global and World Cities: A View from off the Map, International Journal of Urban and Regional Research, 26(3). 
Saith, R. (2001), Social Exclusion: The Concept and Application to Developing Countries. Working Paper 72, Queen Elizabeth house Working Paper Series.

Sassen, S. (1997), Informalisation in Advanced Market Economies, Issues in Development Discussion Paper 20, ILO, Geneva.

Satterthwaite, D., and Hardoy, J. (1993), Helping slum dwellers to help themselves, Down to Earth.

Simone, A. (2004), For the City Yet to Come: Changing African Life in Four Cities. Duke University Press, Durham.

Skinner, C. (2008), Street trade in Africa: A Review, Working Paper no. 51, Manchester, Women in Informal Employment: Globalising and Organising, UK.

Skinner, C. (2010), Street Trading in Africa: Demographic Trends, Planning and Traders Organization, in Padayachee, V. [eds], Political Economy of Africa, Routledge, New York.

Suharto, E. (2003), Accommodating the Urban Informal Sector in the Public Policy Process: A Case Study of Street Enterprises in Bandung Metropolitan Region (BMR), in Indonesia. <http://www.policy.hu/suharto/finalresearchpaper.html> (Accessed on 18 June 2011).

Tsitsi, D. ( 2003), Street Vending in Zimbabwe, Women and Law in Southern Africa, Harare.

UN HABITAT (2012), World Urbanization Prospects. United Nations, Nairobi.

Vargas, A. (2013), Legal Empowerment of Informal Workers: Alternative models of regulation for street vendors in Bogota, Colombia; Paper Presented at the Conference Regulating For Decent Work, 2013.

Watson, V. (2009), The Planned City Sweeps the Poor Away...' Urban Planning and $21^{\text {st }}$ Century Urbanization, Progress in Planning, 72(3).

Williams, C. and Gurtoo, A. (2012), Evaluating Compteing Explanations for Street Enterpreneurship: Some Evidence from India, Journal of Global Enterpreneurship Research, 2(1).

Willemse, L. (2011), Opportunities and constraints facing informal street traders: Evidence from four South African cities, 7-16, SSB/TRP/MDM 2011 (59).

Xaba, J., Horn, P., and Motala, S. (2002), The Informal Sector in Sub-Saharan Africa Employment Sector, 2002/10 Working Paper on the Informal Economy, International Labour Organisation, Geneva. 